\title{
PERTANGGUNGJAWABAN KORPORASI BANK DAN PENYELESAIAN GANTI RUGI TERHADAP NASABAH PENYIMPANAN DANA YANG DIRUGIKAN
}

\section{Fatin Hamamah dan Abdullah}

Universitas 17 Agustus dan CV. Syntax Corporation Indonesia

Email: fatinpdihunissula@gmail.com dan abdullahkhudori62@gmail.com

\begin{abstract}
Appearing Cases of Banking Crimes (TIPIBANK) in the banking world has an impact on the trust of customers when depositing funds into the bank. Banking Crimes (TIPIBANK) in the banking world has an impact on the trust of customers when depositing funds to that bank. So, the trust of the public is decreased because of the scope of the banking world related to the principle of trust. The purpose of the research is to find out how the process and form of accountability for the settlement of the bank's compensation on customers as depositors of funds that have been disadvantaged. The technique is used in this study to use normative juridical methods with a literature study with a statute approach and conceptual approach. The statute approach is the approach taken by identifying and discussing the applicable laws and regulations relating to the material that is discussed. The research produces the following conclusions; 1) The form of law relations between banks and depositing customers can be seen from the relationships that arise from banking products such as deposits, savings, current accounts, etc. 2) The responsibility of the corporation can only be rightfully burdened to the corporation if the criminal act/crime by the management of the corporation is done by person that as the directing mind of that corporation, 3) Settlement of compensation, in this case, is carried out by means of non-litigation and litigation efforts.
\end{abstract}

Keywords: Accountability, bank corporations and customers

\begin{abstract}
Abstrak
Munculnya kasus-kasus Tindak Pidana Perbankan (TIPIBANK) dalam dunia perbankan berdampak terhadap kepercayaan para nasabah penyimpan dana kepada bank tersebut. Sehingga kepercayaan Masyarakat itu menjadi berkurang, karena ruang lingkup dunia perbankan sangat berkaitan dengan asas kepercayaan. Penelitian ini bertujuan untuk mengetahui bagaimana proses dan bentuk pertanggungjawaban penyelesaian ganti pihak bank tergadap nasabah sebagai penyimpan dana yang telah dirugikan. Teknik yang diambil dalam penelitian ini yaitu dengan menggunakan metode yuridis normative dengan studi kepustakaan menggunakan pendekatan perundang-undangan (statute approach) serta pendekatan konseptual (conceptual approach). Statute approach adalah pendekatan yang digunakan dengan mengidentifikasi guna membahas peraturan perundangundangan yang ada sesuai dengan materi yang akan dibahas. Penelitian ini
\end{abstract}


menghasilkan beberapa kesimpulan berikut; 1) Bentuk hubungan hukum bank serta nasabah penyimpan dana bisa terlihat dari hubungan yang ada dari produk-produk perbankan seperti deposito, tabungan, giro, dan sebagainya, 2) Pertanggungjawaban korporasi baru dapat dibenar-benar di bebankan kepada korporasi apabila perbuatan pidana/kejahatan oleh pengurus korporasi tersebut dilakukan oleh orang yang merupakan directing mind dari korporasi tersebut, 3) Penyelesaian ganti rugi dalam hal tersebut, dilakukan dengan cara menempuh upaya non litigasi maupun litigasi.

Kata kunci: Pertanggungjawaban, korporasi bank dan nasabah

\section{Pendahuluan}

Bank merupakan badan usaha yang menghimpun dana dari masyarakat dalam bentuk simpanan serta disalurkan kembali kepada masyarakat dalam bentuk kredit atau dalam bentuk yang lainnya dalam rangka meningkatkan taraf hidup banyak orang (Indonesia, 1998). (Ibrahim, 2003) menyatakan suatu bank hanya bisa melakukan kegiatan serta mengembangkan banknya, jika masyarakat yakin untuk menyimpan uangnya dalam produk produk perbankan yang sudah ada didalam bank tersebut. Berdasarkan kepercayaan Masyarakat bank mampu mengerakkan dana dari Masyarakat supaya disimpan di banknya serta disalurkan kembali kedalam bentuk kredit atau memberikan jasa-jasa perbankan.

Untuk mengambil kembali kepercayaan masyarakat terhadap perbankan nasional, pemerintah melalui instrument hukum pidana memberikan upaya pencegahan terhadap kejahatan perbankan. Kejahatan perbankan yang bermunculan belakangan ini terjadi pada bank miilik pemerintah seperti Bank Nasional Indonesia (BNI), Bank Rakyat Indonesia (BRI) dan Bank Mandiri maupun kasus bank swasta seperti bank Century, City Bank, Bank Mega, Bank Internasional Indonesia (BII), dan Bank Danamon yang kesemuanya itu merupakan bentuk kjahatan perbankan yang melibatkan internal pejabat bank yang bersangkutan tetapi juga pihak lain.

Dalam kaitan ini Soedjono Dirjojoesisworo, menyatakan:

"Kejahatan perbankan sebagai kejahatan dibidang ekonomi dengan berbagai modus operandinya dengan penggunaan komputer sebagai sarana kejahatanya, merupakan kejahatan yang tidak sedikit bahayanya yang dapat mengancam sumber perekonomian sutau negara" (Ibrahim, 2004).

Berbicara tentang pelaku (Plager) tindak pidana perbankan, maka seyogyanya dicermati eksistensi subjek hukum pidana dalam tatanan normatif peraturan perundangundangan kepidanaan. Dengan kata lain, persepsi jangan hanya difokuskan kepada ketentuan pasal 59 kitab undang-undang hukum pidana (selanjutnya disebut KUHP), yang hanya mengenak manusia / perseorangan (naturalij person) sebagai subjek hukum pidana. Akan tetapi persepsi juga diarahkan pada ketentuan undang-undang tentang TIPIBANK ekonomi, undang-undang tentang Pemeberantasan Tindak Pidana Korupsi, Undang-Undang Bank Indoenesia, serta Undang-Undang Perbankan dan lain sebagainya, yang menetukan bahwa subjek hukum pidana disamping orang juga badan hukum (recht person). 
Penetapan kebijakan legislatif (formulatif) yang mengembangkan subjek hukum pidana tersebut, salah satu pertimbangannya didasarkan atas karakteristik dan tipologi dari tindak pidana perbankan yang meliputi pemahaman tentang peristilahan dan pengertiannya modus operandi, perilaku serta korbannya. Berdasrkan studi dan analisis yang telah penulis lakukan terhadap berbagai literatur dan kasus-kasus kejahatan perbankan, karakteristik dan tipologi pelaku kejahatan perbankan sebagian besar dapat diidentikkan dengan pelaku tindak pidana ekonomi, palaku kejahatan korporasi, pelaku kejahatan bisnis, pelaku kejahatan di lingkungan professional, pelaku kejahatan kerah putih, dan pelaku kejahatan komputer.

Berdasarkan uraian yang dijelaskan diatas, maka dapatlah diidentifikasikan siapa saja yang berpeluang dan mempunyai kemungkinan besar untuk melakukan tindak kejahatan perbankan, keiatannya dengan hal tersebut dapat disebutkan pelaku tindak kejahatan perbankan dilakukan oleh:

1.) Oknum pejabat dan pegawai di isntansi terkait;

2.) Pihak terafiliasi;

3.) Nasabah debitur yang berniat buruk;

4.) Anggota masyarakat yang memilki akses untuk melakukanya.

Sulitnya pengungkapan kajatahatan berkerah putih karena faktor-faktor dibidangnya sudah teroraginisir rapih, seperti yang dikatan suyatna "penjahat intelektual ini mempunyai target khusus serta pembagian tugas secara terpisah, misalnya ada pelaku untuk mengatur sekaligus penggagas ide, pelaksana pembuka rekening, penyandang dana, pembuat sekaligus penyedia sarana, maupun alat serta pelaksana pencairan".

Dengan adanya kasus kejahatan bank persepsi masyarakat sebagai nasabah kuran mempercayai keamanan barang berharga maupun uang yang disimpankan dibank. Apabila kepercayaan nasabah dalam menyimpan dana ke bank semakin sedikit, tidak menutup kemungkinan akan terjadi rush terhadap dana yang telah disimpan.

Berdasarkan kepercayaan nasabah terhadap bank, dalam dunia perbankan dikenal adanya asas kepercayaan, menurut Rachamadi Usman asas kepercayaan ialah suatu asas yang mengatakan "usaha bank yang dalam hubungannya selalu dilandasi dengan asas kepercayaan antar bank dengan nasabahnya"(Usman, 2001).

Lebih lanjut Sutan Remi manyatakan "hubungan antara bank dengan nasabah debitor juga bersifat sebagai hubungan kepercayaan yang membebankan kewajibankewajiban kepercayaan kepada bank terhadap nasabahnya"(Sjahdeini, 1993).

Oleh karena itu masyarakat bisnis serta perbankan Indonesia berspekulasi yakni hubungan antara bank dan nasabah debitor adalah juga hubungan yang berlandaskan kepercayaan. Dari pengertian kredit hubungan antar bank dan nasabah bukan hanya sekedar hubungan kontrak belaka, melainkan juga hubungan kepercayaan. Dalam bsinis, yang menjadi jamianan atau yang diterima sebagai penukar uang, barang atau jasa adalah kepercayaan. 


\section{Metode Penelitian}

Paradigma yang diambil untuk penelitian ini ialah paradigma Positivisme, dengan berasumsi bahwa norma hukum selalu terdapat berbagai kepentingan yang relative dengan mewujudkan hukum in abstracto sampai diwujudkan inconcreto yang menjadi objek interpretasi dan konstruksi para pelaku, pengguna dan atau pemanfaatan hukum.

Jenis penelitian yang diambil untuk penelitian ini termasuk dalam penelitian yang bersifat deskriptif analisis, yang tidak hanya menggambarkan permasalahan saja akan tetapi secara kualitatif memiliki interaksi sosial, karena pemahaman simbol-simbol yang digunakan menunjukkan adanya interaksi dalam konteks pertanggungjawaban korporasi bank terhadap dana nasabah yang dirugikan akibat kiprah yang dilakoni oleh pejabat bank.

Pendekatan penelitian yang diambil untuk penelitian ini peneliti memilih Yuridis Normatif, yakni penelitian yang merujuk terhadap norma-norma hukum yang didalamnya berisi tentang peraturan perundang-undangan yang ada sebagai pijakan normative, maka dalam mengelolah dan menganalisi bahan hukum tersebut tidak bisa melepaskan diri dari berbagai penafsiran yang dikenal dalam ilmu hukum (Asikin, 2004).

Teknik yang diambil untuk penelitian ini yaitu dengan menggunakan metode yuridis normative dengan studi kepustakaan dengan pendekatan perundang-undangan (statute approach) serta pendekatan konseptual (conceptual approach). Statute approach ialah pendekatan yang digunakan untuk mengidentifikasi serta membahas peraturan perundang-undangan yang ada berkenaan dengan materi yang akan diulas. Sedangkat pendekatan dengan conceptual approach ialah suatu pendekatan dengan teknik mengulas kembali pendapat para sarjana sebagai acuan pendukung pembahasan dalam penelitian.

\section{Hasil dan Pembahasan}

\section{A. Deskripsi Hubungan Hukum Antara Bank dan Nasabah}

Masalah hubungan antara bank dan nasabah dalam peraturan perundagundangan belum pernah ada yang membahas secara tuntas. L.Budi Kangramanto, "Hubungan bank dengan nasabah bank yang mengandung tiga prinsip yang saling terkait satu dengan yang lain, yaitu hubungan kepercayaan, kerahasiaan, dan keharmonisan (Kagramanto, 2007). Alan L.Tyree dalam bukunya Banking Law In Australia, menyatakan " hubungan antar bank dengan nasabah bisa terlihat dalam berbagai macam segi atau kategori karena tidak mungkin hubungan ini dibakukan dalam satu jenis hubungan saja. Hubungan satu macam segi muncul apabila apabila perselisihan yang mana harus diselesaiakan menurut hukum yang berlaku dan dapat memuaskan para pihak (Tyree, 1990).

Dalam kaitannya dengan prinsip suatu bank, dapat dinayatakan bahwa suatu bank hanya bisa percayauntuk menempatkan uangnya, pada produk-produk perbankan yang ada pada bank tersebut. Berdasarkan keyakinan masyarakat 
tersebut, bank bisa menggerakkan dana dari masyarakat untuk diletakkan pada banknya, serta bank akan memberikan jasa-jasa perbankan.

Berdasarkan pasal 1 angka 5 UU Perbankan disebutkan, jenis dana yang dihimpun oleh bank melalui perjanjian penyimpanan dana bisa berbentuk giro, deposito (deposito berjangka), tabungan dan bentuk-bentuk lainya yang dapat dipersamakan denagn itu. Simpanan masyarakat ini adalah satu diantara sumber dana bank, disamping modal sendiri, serta pinjaman dari pasar uang dan pasar modal.

Berdasarkan dua fungsi utama dari suatu bank, yakni fungsi penghimpun dana dan fungsi penyaluran dana, maka terdapat dua hubungan hukum antara bank dan nasabah, yaitu: (Bako, 1994).

a. Hubungan Hukum Antara Bank dan Nasabah Penyimpan Dana

Artinya, bank menempatkan dirinya sebagai peminjam dana milik Masyarakat (para penanam dana). Produk perbankan yang meliputi tabungan, deposito, giro dan sebagainya kesemuanya adalah merupakan bentuk hubungan hukum yang terjalin antara pihak bank dengan nasabah penyimpan dana. Bentuk hubungan hukum itu tertulis didalam peraturan bank yang sudah dibuat oleh pihak bank dan dilengkapi dengan syarat-syarat umum yang harus dipatuhi oleh setiap nasabah penyimpan dana. Syarat-syarat tersebut harus disesuaikan dengan produk perbankan yang ada, karena syarat dari suatu produk perbankan tidak akan sama dengan syarat dari produk perbankan yang lain. Dalam produk perbankan seperti tabungan dan deposito, maka ketentuan-ketentuan dan syarat-syarat umum yang berlaku adalah ketentuan-ketentuan dan syarat-syarat umum hubungan rekening deposito, dan rekening tabungan.

b. Hubungan Hukum Antara Bank dan Nasabah Debitur

Artinya bank sebagai lembaga penyedia dana bagi para debiturnya. Bentuk hubungan tersebut terdapat dalam perjanjian kredit, seperti kredit modal kerja, kredit investasi, atau kredit usaha kecil.

Dasar hubungan hukum antara bank dan para nasabahnya adalah hubungan kontraktual. Hubungan kontraktual ini terjadi pada saat nasabah menjalin hubungan hukum dengan pihak bank, setelah nasabah melakukan hubungan hukum seperti nasabah membuka rekening tabungan, deposito, dan produk perbankan lainnya.

Terkait denga hubungan hukum antara bank dan nasabah, Sutan Remy Sjahdeini, menjelaskan: "Hubungan hukum antara bank dan nasabah penyimpan dana dituangkan dalam bentuk peraturan bank yang bersangutan yang berisikan ketentuan-ketentuan dan syarat-syarat umum yang harus disetujui oleh nasabah penyimpan dana. Bila dana disimpan dalam bentuk giro, maka ketentuan tersebut yang berlaku adalah ketentuan dan syarat umum hubungan Rekening Koran. Bila dalam bentuk deposito dan tabungan, ketentuan dan syarat umum yang berlaku adalah ketentuan dan syarat umum hubungan rekening deposito atau rekening tabungan. Sebaliknya hubungan hukum anntara bank dan nasabah debitur 
dituangkan dalam perjanjian kredit bank, yang didalm prakatik pada umumnya berbentuk suatu perjanjian standar atau perjanjian baku (Sjahdeini, 1993)".

Di Inggris melalui yurisprudensi telah ditetapkan bahwa hubungan hukum anatara bank dan penyimpan dana merupakan hubungan kontraktual. Ini dapat dilihat dalam kasus Folley v. Hill (1948) 9 E.R. 1002, yang kemudian tealh ditegaskan kembali dalam kasus antara Joachimsoon v. Swiss Bank Corporation (1921) 3K.B.110 (Susanto, n.d.).

Dalam praktek perbankan yang dilakukan selama ini, termasuk di Indonesia, penyerahan dana oleh nasabah, untuk disimpan oleh bank selalu mengandung pengertian bahwa bank yang menerima simpanan tersebut berhk untuk memakai dana tersebut sekehendaknya untuk keperluan apapun juga dan nasabah menyimpan dana sementara tidak mempunyai hak apapun mengenai tujuan pemakaian dana tersebut oleh bank. Hak nasabah penyimpan dana semata-mata hanya berupa hak untuk menagih dan mendapatkan kembali dana tersebut. Praktek perbankan selama ini bersikap bahwa uang atau dana yang telah diserahkan oleh nasabah penyimpan dana kepada bank adalah uang milik bank. Hal ini berarti bahwa dana yang disimpan oleh nasabah merupakan kekayaan bank selama dalam penyimpanan bank.

Dalam praktek perbankan juga berlaku ketentuan bahwa nasabah penyimpan dana yang menyimpan atau meminjamkan uangnya kepada bank dilakukan bukan dengan "Cuma-Cuma", artinya pihak bank harus memberikan bunga kepada nasabah penyimpan dana tersebut.

Dalam hukum Indonesia, hal ini diatur dalam pasal 1765 KUH Perdata disebutkan: "Adalah diperbolehkan memperjanjikan bunga atas pinjaman uang atau lain barang yang menghabis karena pemakaian".

Dapat disimpulkan bahwa hubungan antara bank dan nasabah penyimpan dana merupakan perjanjian peminjaman uang dengan bunga, hal ini sesuai dengan ketentuan pasal 1765 KUH Perdata, maka dana yang disampaikan oleh nasabah adalah milik bank (Asset Bank) selama dalam penyimpanan bank. Dengan perkataan lain, maka sebelum ditagih oleh nasabah atau telah jatuh tempo pihak bank dapat mempergunakannya untuk keperluan praktek perbankan yang mereka lakukan dan dana yang disimpan nasabah merupakan kekayaan bank selama dalam penyimpanan bank, hal ini juga sejalan dengan pasal 1755 KUH Perdata yang menentukan bahwa "pihak yang menerima pinjaman menjadi pemilik barang yang dipinjamkan", dengan kata lain dana yang diserahkan oleh nasabah penyimpan dana kepada bank beralih pemilikannyadari nasabah penyimpan dana kepada bank. 


\section{B. Aspek pertanggungjawaban korporasi bank terhadap nasabah yang dirugikan akibat perbuatan melawan hukum yang dilakukan oleh pejabat bank.}

Korporasi dalam melakukan atau tidak melakukan perbuatan adalah selalu diwakili atau melalui perbuatan perorangan. Lompatan pemikiran harus dilakukan Hakim dalam pertimbangan apakah perbuatan yang dilakukan oleh perorangan dapat dipertanggungjawabkan pada korporasi. Perilaku korporasi akan selalu merupakan tindakan fungsional. Para pelaku (pengurus korporasi) bertindak dalam konteks rangkaian kerja sama antar manusia, in cosu melalui suatu organisasi tertentu. Hoge Raad dalam kasus tersebut memberikan kriteria terkait pertanggungjawaban bagi pemilik perusahaan, yaitu:

a. Apakah kesalahan mengisi formulir termasuk atau tidak termasuk pilihan tindakan yang ada pada terdakwa; dan

b. Apakah terdakwa menerima tindakan seperti itu atau ia biasa menerimanya. (Remmelink \& Moeliono, 2003)

Berdasarkan kriteria itu dapat dikatakan bahwa tindakan yang salah itu harus masuk dalam rentang kekuasaan atau lingkungan kekuasaan pengusaha dan pada umumnya ia harus mengetahui atau menyetujui tindakan yang salah tersebut. Dalam hal korporasi, yang dimaksud adalah terutama lingkup kewenangan dan penerimaan tindakan tersebut oleh pengurus atau organ korporasi.

Teori identifikasi pada dasarnya mengidentikan tindakan dan sikap batin individu yang berhubungan erat dengan korporasi dianggap sebagai tindakan dan sikap batin korporasi itu sendiri. Individ yang melakukan suatu kesalahan dalam lingkup korporasi dengan sendirinya kesalahan itu pada dasarnya adalah kesalahan korporasi. Individu identic dengan korporasi (Ali, 2008). Teori identifikasi ini merupakan teori salah satu teori yang digunakan dalam pembebanan pertanggungjawaban terhadap korporasi yang melakukan kejahatan. Teori ini secara garis besar, mengemukakan agar suatu korporasi dapat dibebani pertanggungjawaban, maka orang yang melakukan perbuatan melanggar hukum harus dapat diidentifikasi terlebih dahulu. Pertanggungjawaban pidana baru dapat benar-benar dibebankan kepada korporasi apabila perbuatan pidana tersebut dilakukan oleh orang yang merupakan directing mind dari korporasi tersebut.

Teori identifikasi memberikan penjelasan bahwa apabila seseorang diberi wewenang untuk bertindak atas nama dan selama menjalankan usaha korporasi tersebut, maka unsur "men rea" yang ada dalam seseorang tersebut dianggap sebagai unsur "men rea" bagi korporasi, sehingga korporasi harus bertanggungjawab atas perbuatan yang dilakukan oleh seseorang (pejabat) di dalam korporasi sepanjang ia melakukannya dalam ruang lingkup kewenangan atau dalam urusan transaksi korporasi (Pramono, 2013). 
Pertanyaan yang muncul adalah bagaimana menentukan siapa yang menjadi directing mind dari sebuah korporasi? Segi formal yuridis, bertitiktolak dari anggaran dasar korporasi, maka akan terlihat jelas siapa yang menjadi pejabat-pejabat yang mengisi posisi tertentu berikut kewenangannya. Lord Diplock mengemukakan bahwa pejabat senior adalah: "mereka-mereka yang berdasarkan memorandum dan ketentuan yayasan atau hasil keputusan paradirektur atau putusan rapat umum perusahaan, telah dipercaya melaksanakan kekuasaan perusahaan". Dasar yang harus depergunakan untuk mengidentifikasi, para pribadi yang dapat dianggap sebagai orang yang mewakili korporasi adalah akta pendirian dan Anggaran Dasar korporasi atau Hasil Keputusan Rapat Umum Pemegang Saham yang dipercayakan untuk melaksanakan kewenangankewenangan perusahaan (Arief, 2003).

Kenyataan daam praktik operasional korporasi, pejabat senior yang secara formal yuridis mempunyai kewenangan dalam mengambil keputusan dalam korporasi ternyata berada di bawah pengaruh pihak yang secara factual lebih memegang kendali, misalnya para pemegang saham (shareholders).

Dalam praktik penanganan perkara, pada umumnya tidak mudah menetapkan kualifikasi gugatan, meskipun secara teoritis sebagaimana dikemukakan di atas bahwa kualifikasi gugatan setidaknya dapat dibedakan menjadi 3 (tiga), yaitu wanprestasi (ingkar janji), perbuatan melanggar hukum (onrechtmatigedaad) dan perbuatan melawan hukum penguasa (onrechtmatigeoverheids daad).

Disamping tanggungjawab palaku usaha/korporasi sebagaimana yang diatur dalam undang-undang No. 8 Tahun 1999 tentang Perlindungan Konsumen (selanjutnya disebut UU Perlindungan Konsumen) pada pasal 19, hak-hak konsumen diatur dalam Pasal 4 UU Perlindungan Konsumen. Hak-hak konsumen sebagaimana telah dikemukakan di atas, hanyalah mungkin ditegakkan apabila pelaku usaha bersedia dengan sukarela memenuhi tuntutan konsumen terhadap pemenuhan hak-haknya yang dilanggar oleh pelaku usaha. Jika pelaku usaha tidak mau melaksanakannya dengan cara sukarela, sedang konsumen berasumsi bahwa pelaku usaha yang bersangkutan telah melakukan perbuatan melanggar dengan ketentuan UU perlindungan Konsumen dan merugikannya, maka pnegakan hak-hak konsumen/nasabah itu hanya dapat dituntut melalui proses penyelesaian sengketa yang ditentukan di dalam UU Perlindungan Konsumen.

Berdasarkan pasal 45 ayat (2) UU Perlindungan Konsumen, sistem penyelesaian sengketa dapat ditempuh dengan dua jalur yaitu pertama melalui jalur pengadilan dan kedua melalui jalur non penagdilan, sesuai dengan kehdendak para pihak yang bersengketa. Dengan demikian, apakah konsumen akan berperkara di pengadilan atau di luar pengadilan adalah pilihan sukarela para pihak. Kata sukarela harus diartikan sebagai pilihan para pihak baik sendiri-sendiri atau bersama-sama untuk menempuh jalan penyelesaian di pengadilan atau di luar pengadilan. 
Dalam kaitan ini Pasal 23 UU perlindungan Konsumen menentukan bahwa: " pelaku usaha yang menolak dan/atau tidak memberi tanggapan dan/atau memenuhi ganti kerugian atas tuntutan konsumen sebagaimana dimaksud dalam pasal 19 ayat (1) sampai dengan ayat (1), dapat digugat melalui Badan Penyelesaian Sengketa Konsumen (BPSK) atau mengajukan ke badan peradilan di tempat kedudukan konsumen".

Setelah berlakunya UU Perlindungan Konsumen, perlakuan terhadap konsumen korban tindak pidana dibidang perlindungan konsumen, telah berubah, baik dari segi peraturan hukumnya sendiri, maupun praktik peradilan. Penempatan dalam sistem UU Perlindungan Konsumen menjamin kepentingan dan hak-hak serta kewajiban kedua belah pihak, yaitu hak dan kewajiban para pihak yang bersifat timbal balik. Hak konsumen merupakan kewajiban usaha untuk memenuhinya, sebaliknya hak pelaku usaha merupakan kewajiban konsumen untuk memenuhinya, seperti yang diatur dalam Pasal 4 dan Pasal 5 Bab III Bagian Pertama UU Perlindungan Konsumen (hak dan kewajiban konsumen) serta Pasal 6 dan Pasal 7 Bab III Bagian kedua UU Perlindungan Konumen (hak dan kewajiban pelaku usaha).

Pelaku usaha/bank bertanggungjawab memberikan ganti rugi atas kerugian konsumen/nasabah akibat mengonsumsi jasa perbankan yang dihasilkan oleh bank. Ganti rugi tersebut dapat berupa pengembalian uang. Ketentuan tersebut tidak berlaku apabila pelaku usaha dapat membuktikan bahwa kesalahan tersebut merupakan kesalahan konsumen.

UU Perlindungan Konsumen telah mengubah paradigma lama yang kurang berorientasi kepentingan/hak konsumen. Pasal 63 butir c UU Perlindungan Konsumen telah menempatkan hukuman tambahan berupa pembayaran ganti kerugian atas pelanggaran-pelanggaran norma-norma UU Perlindungan Konsumen, disamping dijatuhkan sanksi pidana pokok berupa:

1. Pidana penjara maksimal 5 (lima) tahun atau pidana denda maksimal Rp 2.000.000.000,- (dua miliar rupiah); dan

2. Pidana penjara maksimal 2 (dua) tahun atau pidana denda maksimal $\mathrm{Rp}$ 500.000.000,- (lima ratus juta rupiah).

Paradigma baru ini, tanpa diajukannya tuntutan atau gugatan ganti kerugian oleh saksi korban atau pihak ketiga lainnya yang dirugikan, akibat tindak pidana dibidang perlindungan konsumen, penuntut umum ketika mengajukan tuntutan pidana di persidangan, dapat mengajukan tuntutan tambahan berupa pembayaran ganti kerugian. Hakim yang mengadili tidak terpaku pada pasal 99 Ayat (2) KUHP yang menentukan bahwa tuntutan ganti kerugian yang dikabulkan terbatas pada penggantian biaya yang telah dikeluarkan oleh pihak ketiga (termasuk saksi korban) yang dirugikan. Sikap yang semestinya ini tidaklah melanggar hukum acara pidana (KUHAP).

Berdasarkan Pasal 19 Ayat (4) UU Perlindungan Konsumen menegaskan: "Pemberian ganti kerugian oleh pelaku usaha atas kerugian konsumen akibat 
mengonsumsi jasa tidaklah menghapus kemungkinan tuntutan pidana." Demikian pula penyelesaian sengketa di luar pengadilan tidak menghilangkan tanggungjawab pidana sebagaimana diatur dalam undang-undang ini (Pasal 45 Ayat (3) UU Perlindungan Konsumen). Ada 2 (dua) hal yang perlu dicermati pada Pasal 22 UU Perlindungan Konsumen tersebut:

Pertama, dikatakan sebagai kasus pidana, apabila unsur-unsur suatu tindak pidana sesuai dengan sistem pidana telah dijalankan, seperti penyidikan, penuntutan suatu tindak pidana di bidang Perlindungan Konsumen.

Kedua, kasus pidana yang dimaksudkan dalam Pasal 22 UU Perlindungan Konsumen tersebut berkaitan dnegan ketentuan-ketentuan Pasal 19 Ayat (4), Pasal 20, dan Pasal 21 UU Perlindungan Konsumen menegaskan bahwa pemberian ganti kerugian oleh pelaku usaha atas kerugian konsumen akibat mengkonsumsi atau jasa tidaklah menghapuskan kemungkinan tuntutan pidana berdasarkan pembuktian terbalik tentang ada tidaknya unsur kesalahan. Salah satu bagian penting dalam penyelesaian sengketa perdata konvensional, adalah beban pembuktian (bewijslast/burden of proof). Kepada pihak mana ditetapkan beban pembuktian apabila timbul suatu perkara. Keliru menetapkan beban pembuktian dapat menyebabkan kerugian terhadap pihak yang dibebani, dan memberi keuntungan kepada pihak yang lain.

Untuk menghindari kesalahan pembebanan pembuktian yang tidak proporsional, sehingga merugikan kepantingan pihak lainnya, maka dalam menerapkan beban pembuktian harus dilihat kasus perkasus, menurut keadaan yang konkret, dan perlu dipahami prinsip dan praktik yang berkenaan dengan penerapannya.

Pasal 19 ayat (1) UU Perlindungan Konsumen menentukan bahwa pelaku usaha bertanggungjawab memberikan ganti kerugian atas kerusakan, pencemaran dan/atau kerugian konsumen akibat mengonsumsi barang dan/atau jasa yang dihasilkan atau diperdagangkan, dengan bentuk ganti kerugian yang ditentukan dalam pasal 19 Ayat (2) UU Perlindungan Konsumen. Jika dikaitkan dengan Pasal 1246 KUH Perdata ganti kerugian terdiri dari 2 (dua) factor, yaitu:

a. Kerugian yang nyata-nyata diderita, dan

b. Kerugian lainnya, atau keuntungan yang seharusnya diperoleh.

\section{Proses Penyelesaian ganti rugi terhadap dana nasabah yang dirugikan akibat perbuatan melawan hukum yang dilakukan oleh pejabat bank.}

Ketentuan dalam Pasal 2 Ayat (2) Peraturan Bank Indonesia Nomor 7/7/PBI/2005 tentang Penyelesaian Pengaduan Nasabah, sebagaimana telah diubah dengan Peraturan Bank Indonesia Nomor 10/10/PBI/2008 (selanjutnya disebut PBI-Penyelesaian Pengaduan Nasabah) telah mewajibkan semua Bank umum dan Bank Perkreditan Rakyat untuk menyelesaikan setiap pengaduan yang diajukan nasabah dan/atau perwakilan nasabah. Maka, setiap nasabah disini, selain pihak yang menggunkan jasa bank, termasuk pula pihak yang tidak 
memiliki rekening namun memanfaatkan jasa bank untuk melakukan transaksi keuangan (walk-in customer). Hal ini berarti bahwa setiap pengguna jasa bank baik yang memiliki rekening ataupun pengguna jasa bank untuk melakukan transaksi keuangan dapat pula mengajukan pengaduan.

Model penyelesaian sengketa melalui pengaduan nasabah, dalam struktur penyelesaian sengketa perlindungan konsumen termasuk penyelesaian secara damai di luar pengadilan sebagaimana dinmanfaatkan dalam UU Perlindungan Konsumen. Secara Prosedural, konsep "Pengaduan Nasabah" haruslah berlandaskan pada filosofis keseimbangan kedudukan nasabah bank sebagai konsumen dan pihak perbankan. Reulasi proses penyelesaiannya harus menjaminb bahwa proses penyelesaian tersebut tidak semakin memperlihatkan posisi pelaku usaha sebagai pihak yang kuat dan pihak nasabah sebagai konsumen datang mengadu dalam posisi meminta-minta belas kasihan kepada pihak bank. Oleh karena itu, apabila mekanisme penanganan pengaduan nasabah ini merupakan wujud integrasi dan harmonisasi hukum perbankan dan perlindungan konsumen, maka ada jaminan bahwa regulasi tersebut dimaksudkan untuk menempatkan kedua belah pihak secara seimbang.

Berkenaan dengan keberadaan unit dan/atau fungsi khusus penyelesaian pengaduan nasabah, ketentuan dalamPasal 5 PBI-Penyelesaian Pengaduan Nasabah mewajibkan Bank Umum dan Bank Perkreditan Rakyat mempublikasikan kepada Masyarakat secara tertulis dan/atau elektronis.

Menurut PBI-Penyelesaian Pengaduan Nasabah, nasabah dapat mengajukan atau mengajukan atau menyampaikan pengaduan, bisa secara tertulis dan/atau lisan, yang berisikan penjelasan inti permasalaha yang akan diadukan dan apa yang akan diharapkan dari bank.

Menurut Rachmadi Usman, terdapat dua cara yang dapat ditempuh nasabah untuk mengajukan pengaduan, yaitu:

1. Secara lisan

a. Diajukan secara langsung ke kantor bank terdekat, kantor bank tempat nasabah membuka rekening atau kantor bank temapat nasabah melakukan transaksi keuangan;

b. Melalui telepon, termasuk call center (layanan 24 jam) yang tersedia.

2. Secara tertulis

a. Membuat dan menyampaikan surat resmi dengan jelas serta dengan mengungkapkan kronologis dan lokasi terjadinya permasalahan, baik diantar langsung, atau dikirim melalui faksmili atau melalui pos ke bank yang bersangkutan;

b. Melalui e-mail atau website bank;

c. Melalui sarana elektroniklainnya;

d. Mengisi formulir pengaduan yang tersedia pada setiap kantor bank;

e. Pengaduan secara tertulis wajib dilengkapi fotocopi identitas dan Dokumen pendukung lainnya yang mendasari transaksi keuangan. 
Pengaduan nasabah tersebut dapat disampaikan kepada kantor bank terdekat, kantor bank tempat nasabah membuka rekening atau kantor bank tempat nasabah melakukan transaksi keuangan. Ketentuan dalam Pasal 7 ayat (1) PBI-Penyelesaian Pengadaan nasabah, menetapkan baha penerimaan pengaduan nasabah dapat dilakukan pada setiap kantor bank dan tidak terbatas hanya pada kantor bank tempat nasabah membuka rekening dan/atau kantor bank tempat nasabah melakukan transaksi keuangan. Jadi, seluruh kantor bank yang bersangkutan dapat menerima pengaduan nasabah.

Terdapat akibat hukum dari kejahatan dibidang perbankan sehingga bank dikategorikan sebagai bank bermasalah. Dalam hal ini diajukan beberapa mekanisme yang dipergunakan dalam rangka perlindungan dana nasabah bank sebagai berikut:

a. Pembuatan Peraturan Baru

b. Pelaksanaan Peraturan yang Ada

c. Perlindungan Nasabah deposan lewat lembaga asuransi deposito

d. Memperketat perizinan bank

e. Memperketat pengaturan dibidang kegiatan bank

f. Memperketat pengawasan bank

\section{Kesimpulan}

Bentuk hubungan hukum bank dan nasabah penyimpan dana dapat terlihat dari hubungan yang muncul dari produk-produk perbankan seperti deposito, tabungan, giro, dan sebagainya. Dalam hal ini bank menempatkan dirinya sebagai peminjam dana milik Masyarakat (para penanam dana). Bentuk hubungan hukum itu, dapat tertuang dalam bentuk peraturan bank yang bersangkutan dan syarat-syarat umum yang harus dipatuhi oleh setiap nasabah penimpan dana.

Pertanggungjawaban setiap korporasi bank terhadap nasabah bank yang dirugikan akibat dari perbuatan penyimpangan (pelanggaran) yang dilakukan oleh pejabat bank, dalam hal ini harus diketahui terlebih dahulu bahwa korporasi dalam melakukan perbuatan adalah selalu diwakili atau melalui perbuatan pengurursnya, untuk mempertanggungjawabkan perbuatan pengurusnya, untuk mempertanggungjawbakan perbuatan pengurus tadi tersebut, maka digunakan teori identifikasi yang secara garis besar mengemukakan agar suatu korporasi dapat dibebani pertanggungjawaban, maka orang yang melakukan perbuatan melanggar hukum atau kejahatan harus dapat diidentifikasi terlebih dahulu. dengan demikian pertanggungjawaban korporasi baru dapat dibenar-benar di bebankan kepada korporasi apabila perbuatan pidana/kejahatan oleh pengurus korporasi tersebut dilakukan oleh orang yang merupakan directing mind dari korporasi tersebut. Teori identifikasi memberikan penjelasan bahwa apabila seseorang diberi wewenang untuk bertindak atas nama dan selama menjalankan usaha korporasi tersebut, maka unsur men rea yang ada dalam diri seseorang tersebut dianggap sebagai unsur men rea bagi korporasi, sehingga korporasi harus bertanggungjawab atas perbuatan yang dilakukan oleh seorang pejabat didalam 
korporasi sepanajang ia melakukannya dalam ruang lingkup kewenangan atau dalam urursan transaksi korporasi.

Model penyelesaian ganti rugi terhadap dana nasabah yang dirugikan akibat perbuatan menyimpang (pelanggaran) yang dilakukan oleh pejabat bank. Penyelesaian ganti rugi dalam hal tersebut, dilakukan dengan cara menempuh upaya non litigasi maupun litigasi, dalam hal ini dapat ditempuh melalui pengaduan nasabah ke bank tempat dia buka rekening dan tembusan pengaduan tersebut ke Bank Indonesia, terhadap nasabah yang tidak puas terhadap penyelesaian melalui bentuk pengaduan, maka nasabah dapat menempuh upaya mediasi melalui arbitrase ataupun lembaga mediasi perbankan yang dibentuk oleh asosiasi perbankan, dan apabila nasabah tetap tidak puas dengan model penyelesaian melalui mediasi bank, maka nasabah dapat menyelesaiakan sengketa ke BPSK, maupun gugatan perdata di pengadilan atas dasar wanprestasi. 
Pertanggungjawaban Korporasi Bank dan Penyelesaian Ganti Rugi Terhadap Nasabah

Penyimpanan Dana yang Dirugikan

\section{BIBLIOGRAFI}

Ali, M. (2008). Kejahatan korporasi: Kajian relevansi sanksi tindakan bagi penanggulangan kejahatan korporasi. Arti Bumi Intaran.

Arief, B. N. (2003). Kapita selekta hukum pidana. Citra Aditya Bakti.

Asikin, Z. (2004). Amiruddin, Pengantar Metode Penelitian Hukum. Jakarta: Raja Grafindo Persada.

Bako, R. S. H. (1994). Hubungan bank dan nasabah terhadap produk tabungan dan deposito: suatu tinjauan hukum terhadap perlindungan deposan di Indonesia dewasa ini.

Ibrahim, J. (2003). Pengimpasan Pinjaman (Kompensasi) dan Asas Kebebasan Berkontrak dalam Perjanjian Kredit Bank. Utomo.

Ibrahim, J. (2004). Kartu kredit: dilematis antara kontrak dan kejahatan. Refika Aditama.

Indonesia, P. R. (1998). Undang-undang Republik Indonesia nomor 10 tahun 1998 tentang perubahan atas Undang-undang nomor 7 tahun 1992 tentang perbankan. BP. Cipta Jaya.

Kagramanto, I. B. (2007). Eksistensi Lembaga Penjamin Simpanan dalam Sistem Perbankan Nasional. Mimbar Hukum-Fakultas Hukum Universitas Gadjah Mada, 19(3).

Pramono, W. (2013). Pertanggungjawaban pidana korporasi hak cipta. Bandung: Alumni.

Remmelink, J., \& Moeliono, T. P. (2003). Hukum pidana: komentar atas pasal-pasal terpenting dari kitab undang-undang hukum pidana belanda dan padanannya dalam kitab undang-undang hukum pidana indonesia. Gramedia Pustaka Utama.

Sjahdeini, S. R. (1993). Kebebasan berkontrak dan perlindungan yang seimbang bagi para pihak dalam perjanjian kredit bank di Indonesia. FH-UI.

Susanto, M. (n.d.). Kedudukan Dana Aspirasi Dewan Perwakilan Rakyat dalam Ketatanegaraan Indonesia.

Tyree, A. L. (1990). Banking law in Australia. Butterworths.

Usman, R. (2001). Aspek-aspek hukum perbankan di Indonesia. Gramedia Pustaka Utama. 